\title{
Functional product enriched with the microencapsulated extract of cupuassu (Theobroma grandiflorum Schum.) seed by-product
}

\author{
Russany Silva da COSTA ${ }^{1}$ (D), Orquídea Vasconcelos dos SANTOS², Antônio Manoel da Cruz RODRIGUES ${ }^{3}$, \\ Roseane Maria RIBEIRO-COSTA ${ }^{4}$, Attilio CONVERTI ${ }^{5}$, José Otávio Carréra SILVA JÚNIOR ${ }^{1 *}$
}

\begin{abstract}
This work deals with the application of microencapsulated extract of cupuassu seed by-product to functionally enrich a food multimixture. The methodological bases applied were those of the Official Methods of Analysis of AOAC. Multimixture enrichment with the extract led to 54 and 19\% increases in total dietary fiber and total fat contents, to slight decreases in carbohydrate and protein contents, while the total energy value was reduced by $6.4 \%$ due to the increase in unsaturated fatty acids content. The enriched multimixture showed a significant antioxidant activity and high levels of $\mathrm{Ca}^{2+}, \mathrm{Fe}^{2+}, \mathrm{Zn}^{2+}$ and $\omega-9$ and $\omega-6$ unsaturated fatty acids. Nutritional and functional qualities of this multimixture, as well as its excellent stability against progressive temperature increases frequently occurring in food preparations, suggest its use as a basic ingredient for food supplementation. The results also indicate excellent technological properties of the multimixture to formulate new food products.
\end{abstract}

Keywords: functional food; antioxidant activity; functional composition; food technology; agroindustrial by-product; multimixture.

Practical Application: Functional product containing by-product of cupuassu has good technological potential as food.

\section{Introduction}

Malnutrition has always been considered a major and undeniable problem in the socioeconomic scenario of underdeveloped world and so-called developing countries such as Brazil. According to estimates of Food and Agriculture Organization of the United Nations, there are 821 million people worldwide and 39.3 million in Latin America and the Caribbean under this condition (Food and Agriculture Organization of the United Nations, 2017).

This context gave rise the so-called Alternative Feeding, whose name is used to designate the proposal to promote the use of unconventional foods or agroindustrial by-products accessible to the entire population (Hernandez-Santos et al., 2015; Molina Ramírez et al., 2018). In this scenario, the so-called "multimixture flour" or simply "multimixture" (MM) can be defined as a product obtained, basically, by mixing bran, seeds, dark green leaf powder and eggshells. In view of the above, MM is a social strategy of food supplement/complement that aims to combat infant mortality and malnutrition.

However, MM efficiency in reducing malnutrition has generated controversial opinions between entities that disseminate it and scientific community, since most of scientific work has shown some fragility in the arguments in favor of its supposed benefits to human health (Madruga et al., 2004; Ferreira et al., 2010).

In this sense, studies highlighting the potential of using agroindustrial by-products to formulate new ingredients or "sub-ingredients" for food enrichment are of great significance, because this practice would be an economical alternative for agroindustries as well as for environmental sustainability (Esteller et al., 2006; Pugliese et al., 2013; Can-Cauich et al., 2017; Da Costa et al., 2018). The recovery of agro-industrial fruit by-products has gained growing interest because of the possibility of exploiting their bioactive compounds. Among them, the by-product of cupuassu (Theobroma grandiflorum Schum.) has great potential as a source of functional compounds and antioxidants (Da Costa et al., 2018).

Faced with this situation and due to insufficient scientific evidence justifying the consumption of traditional multimixtures, it is necessary to incorporate enriching nutritional components into new, safer and scientifically-tested formulations.

In this context, with the purpose of contributing to the prevention and reduction of infant malnutrition in riverside populations of the Amazon region, in this study we evaluated the physicochemical, thermal, nutritional and functional properties of a) the microencapsulated extract of cupuassu seed by-product, b) a basic formulation already used by Child's Pastoral in conjunction with the Brazilian National Conference of Bishops (CNBB), and c) another multimixture obtained by adding to this formulation microparticles prepared under optimum spray drying conditions.

${ }^{1}$ Laboratório de PひD Farmacêutico e Cosmético, Faculdade de Ciências Farmacêuticas, Universidade Federal do Pará, Belém, PA, Brasil

${ }^{2}$ Laboratório de Ciências dos Alimentos, Faculdade de Nutrição, Universidade Federal do Pará, Belém, PA, Brasil

${ }^{3}$ Laboratório de Medidas Físicas, Faculdade de Engenharia de Alimentos, Universidade Federal do Pará, Belém, PA, Brasil

${ }^{4}$ Laboratório de Nanotecnologia Farmacêutica, Faculdade de Ciências Farmacêuticas, Universidade Federal do Pará, Belém, PA, Brasil

${ }^{5}$ Dipartimento di Ingegneria Civile, Chimica e Ambientale, Scuola Politécnica, Università degli Studi di Genova, Genova, Italy

*Corresponding author: carrera@ufpa.br 


\section{Material and methods}

\subsection{Preparation of microencapsulated extract of cupuassu seed by-product}

The extract of cupuassu seed by-product was obtained from percolation extraction, the whole process is described in the methodology of Costa et al. (2019). And the microencapsulated extract of cupuassu seed by-product (ME) was obtained by spray drying (Mini Spray Dryer, model B-290, Büchi, Flawil, Switzerland) using maltodextrin as a coating material under optimal microencapsulation conditions, which were previously established according to a $3^{3}$-Box-Beheken factorial design (Da Costa et al., 2018).

\subsection{Multimixture composition and preparation}

The conventional multimixture (MM I) used in this study consisted of $42.5 \%$ rice bran, $42.5 \%$ maize corn, $4.0 \%$ sunflower seed, $0.5 \%$ cabbage leaf powder and $0.5 \%$ eggshell powder, while the enriched multimixture (MM II) was obtained by adding $10 \%$ of ME to MM I. All ingredients were sanitized, and eggshells washed in running water and submerged in a $1.0 \%$ sodium hypochlorite solution for disinfection. The components were pulverized in a variable speed rotor mill, model Pulverisette 14 (Fritsch, Idar-Oberstein, Germany), under $150 \mathrm{rpm}$ agitation for $180 \mathrm{~s}$, and then weighed and mixed in a solids mixer, model Mixer plus (Tepron, São Paulo, SP, Brazil), at $3000 \mathrm{rpm}$ for $45 \mathrm{~min}$. Samples of MM I and MM II were packed and stored under refrigeration $\left(8^{\circ} \mathrm{C}\right)$ and protected from light until analyses.

\subsection{Determination of centesimal composition}

Samples were submitted to drying using a moisture analyzer coupled to a balance with infrared radiation, model IV 2000 (Gehaka, São Paulo, SP, Brazil). Drying was performed at $105^{\circ} \mathrm{C}$ until constant weight, and values were expressed as percentages.

Total ashes were quantified by calcination, according to the method of Association of Official Analytical Chemists (2010). Samples were carbonized in muffle $\left(550 \pm 2{ }^{\circ} \mathrm{C}\right)$ and subsequently weighed. To calculate the wet (WAC) and dry (DAC) ash contents, the following Equations 1 and 2 were used:

$$
\begin{aligned}
& \operatorname{WAC}(\%)=\frac{M_{\mathrm{f}}-\mathrm{M}_{\mathrm{i}}}{\mathrm{M}_{\mathrm{s}}} \times 100 \\
& \operatorname{DAC}(\%)=\frac{\mathrm{WAC}}{100-\mathrm{WC}} \times 100
\end{aligned}
$$

where $M_{\mathrm{f}}(\mathrm{g})$ is the sample mass after ashing, $M_{\mathrm{i}}(\mathrm{g})$ the tare mass of crucible, $M_{s}$ the original sample mass and WC (\%) the water content.

The protein content was determined by the Kjeldahl method using the nitrogen conversion factor for total proteins of 6.25 , while that of lipids by solid-liquid extraction with petroleum ether, using a Soxhlet extractor. In both cases, the AOAC methodologies (Association of Official Analytical Chemists, 2010) were used.
The total dietary fiber was determined according to the enzymatic-gravimetric AOAC 985.29 method, the insoluble one according to the AOAC 991.42 method and the soluble one by difference of the last two terms (Association of Official Analytical Chemists, 2010).

The carbohydrate content, expressed in \%, was obtained by difference between 100 and the sum of the other contents (moisture, ashes, proteins, lipids and total dietary fiber), while the caloric value was determined applying the Atwater factors 4,9 and $4 \mathrm{kcal} / 100 \mathrm{~g}$ for proteins, lipids and carbohydrates, respectively. Both determinations were done according to the Food and Drug Administration (Food and Drug Administration, 2018).

\subsection{Determination of fatty acid composition}

Oil fractions of MM I and MM II were extracted by solid-liquid separation using petroleum ether (Association of Official Analytical Chemists, 2010). After extraction, the oil was stored under refrigeration at $-7^{\circ} \mathrm{C}$.

Fatty acid composition was determined by conversion to their methyl esters (FAMEs) (Rodrigues et al., 2010), which were analyzed by means of a gas chromatograph, model CP 3380 (Varian, Walnut Creek, CA, USA), equipped with a flame ionization detector (FID) and a CP-Sil 88 (Varian) capillary column with a length of $60 \mathrm{~m}$, internal diameter of $0.25 \mathrm{~mm}$ and film thickness of $0.25 \mu \mathrm{m}$. The following conditions were adopted: helium as transport gas at a flow rate of $0.9 \mathrm{~mL} / \mathrm{min}$, detector and injector temperature of $250^{\circ} \mathrm{C}$ and injection volume of $1.0 \mu \mathrm{L}$. Column temperature was initially set at $175^{\circ} \mathrm{C}$ for $8 \mathrm{~min}$, increased by $2.0^{\circ} \mathrm{C} / \mathrm{min}$ to $180^{\circ} \mathrm{C}$, held at this temperature for $28 \mathrm{~min}$, then again increased by $2.0^{\circ} \mathrm{C} / \mathrm{min}$ to $250^{\circ} \mathrm{C}$, and maintained at this temperature for $10 \mathrm{~min}$. Individual peaks of FAMEs were identified by comparison of retention times with those of standard FAMEs (74 X Nu-Chek-Prep, Inc., Elysian, MN, USA), which were analyzed under the same operating conditions. The retention time and area of each peak were calculated using the software Varian Star 3.4.1, and the results expressed as relative percentages of total fatty acids (Bezerra et al., 2017).

\subsection{Evaluation of functional quality of lipid fractions}

The functionality of multimixture lipid fractions was based on their fatty acid profiles. For this purpose, the indices of atherogenicity (AI) and thrombogenicity (TI) were calculated according to Ulbricht \& Southgate (1991), the following Equations 3 and 4 were used:

$$
\begin{aligned}
& \mathrm{AI}=\frac{\mathrm{C} 12: 0+4 * \mathrm{C} 14: 0+\mathrm{C} 16: 0}{\Sigma \mathrm{MUFA}+\Sigma \mathrm{FA} \omega 6+\Sigma \mathrm{FA} \omega 3} \\
& \mathrm{TI}=\frac{\mathrm{C} 14: 0+\mathrm{C} 16: 0+\mathrm{C} 18: 0}{(0,5 * \Sigma \mathrm{MUFA})+(0,5 * \Sigma \mathrm{FA} \omega 6)+(3 * \mathrm{FA} \omega 3)}
\end{aligned}
$$

where the acronyms MUFA, FAw3 and Faw6 indicate the monounsaturated fatty acids and fatty acids with 3 and 6 insaturations, respectively, while the ratio of hypocholesterolemic to hypercholesterolemic compounds $(\mathrm{HH})$ according to Santos-Silva et al. (2002), the following Equation 5 was used: 
$\mathrm{HH}=\frac{\left(\begin{array}{l}\mathrm{C} 18: 1 \omega 9+\mathrm{C} 18: 2 \omega 6+\mathrm{C} 20: 4 \omega 6+\mathrm{C} 18: \\ 3 \omega 3+\mathrm{C} 20: 5 \omega 3+\mathrm{C} 22: 5 \omega 3+\mathrm{C} 22: 6 \omega 3\end{array}\right)}{(\mathrm{C} 14: 0+\mathrm{C} 16: 0)}$

\subsection{Micronutrient composition: macro and microminerals}

Samples of MM I and MM II were weighed $(0.25 \mathrm{mg})$ and subjected to acid digestion in a microwave oven, model Start E (Milestone, Sporisole, Italy). Concentrated $\mathrm{HNO}_{3}(8.0 \mathrm{~mL})$ and $30 \%$ $(\mathrm{w} / \mathrm{w}) \mathrm{H}_{2} \mathrm{O}_{2}(4.0 \mathrm{~mL})$ were added to the samples. This procedure was performed in two stages. In the former stage, the system was heated at $180{ }^{\circ} \mathrm{C}$ at a power of $800 \mathrm{~W}$ for $36 \mathrm{~min}$, while in the latter it was simply ventilated for $50 \mathrm{~min}$. After acid digestion, the samples were diluted in ultra-pure water and filtered through a membrane with $0.20 \mu \mathrm{m}$-pore diameter (Millipore, Bedford, MA, USA). Afterwards, they were analyzed with an Inductively Coupled Plasma Optical Emission Spectrometer, model ICP-OES, CAP 6500 Duo (Thermo Fisher Scientific, Cambridge, UK), with concentric nebulization chamber, radio-frequency power of $1.15 \mathrm{kw}$, flow rate of plasma gas of $12 \mathrm{~L} / \mathrm{min}$ and nebulized gas flow rate of $0.5 \mathrm{~L} / \mathrm{min}$. After the construction of curves, $\mathrm{Fe}$, $\mathrm{Na}, \mathrm{Mg}, \mathrm{Mn}, \mathrm{K}, \mathrm{P}, \mathrm{Ca}, \mathrm{Zn}$ and $\mathrm{Pb}$ were analyzed.

\subsection{Morphological analysis by Scanning Electron Microscopy}

Degreased samples (ME, MM I and MM II) were deposited on a sample holder with the aid of a carbon tape and metallized with Au/Pd using a metallizer, model SC7620 (Quorum Technologies, Lewes, UK). Metallization was performed for $2.0 \mathrm{~min}$ with $5.0 \mathrm{~mA}$ current. Electromicrographs were obtained using a scanning electron microscope, model VEGA 3 (Tescan, Cranberry Township, PA, USA), with 85-90- $\mu$ A electron beam current and $10.0-\mathrm{kV}$ acceleration voltage. Micrometric scales were designed in the same optical conditions.

\subsection{Determination of thermal profile by thermogravimetry}

The TGA/DTG curves of ME, MM I and MM II were obtained using a thermal analyzer, model TGA 50/50H (Shimadzu, Kyoto, Japan). Samples were weighed (5-10 mg) in platinum crucible and analyzed under $\mathrm{N}_{2}$ atmosphere at a flow rate of $50 \mathrm{~mL} / \mathrm{min}$. Tests were carried out in the temperature range of $25-600^{\circ} \mathrm{C}$ with a heating rate of $10{ }^{\circ} \mathrm{C} / \mathrm{min}$ (Sampaio et al., 2016). The results were analyzed by the TA-60W-Shimadzu software.

\subsection{Statistical analysis}

Experimental data were subjected to one-way analysis of variance (ANOVA) and Tukey's multiple-range test, using the Statistica version 7.0 software (StatSoft Inc., Tulsa, OK, USA). Differences were considered to be significant at $p<0.05$.

\section{Results and discussion}

\subsection{Functional potential of multimixtures}

Cupuassu seeds by-product extract showed significant values of macro and micronutrients, as well as phenolic compounds that give it an important antioxidant activity (Costa et al., 2019).
Both MM I and II formulations showed satisfactory contents of the main macronutrients with nutritional relevance, namely carbohydrates, proteins and total dietary fiber (Table 1). Even the total energy value (TEV) of MM I was about 7\% higher than that of MM II, this did not mean a better functional quality, since it was related to higher percentage of saturated fats.

$\mathrm{ME}$ addition to the multimixture led to a generalized functional improvement, i.e. 27 and 23\% reductions in carbohydrate and saturated fat contents, respectively, the addition of polyphenols contained in $\mathrm{ME}$, and a parallel increase in unsaturated fat content, consistently with the $19 \%$ increase in MM II total fat content.

All contents of these components are consistent with recommended daily intakes (RDIs) (Table 1). It is noteworthy that the formulations showed statistically significant differences $(p<0.05)$ in protein and lipid contents that can be attributed to the multmixture oily components (sunflower seeds and by-product of cupuassu seeds that still had around 3 to $4 \%$ of crude oil).

Studies on different multimixtures showed that those containing soybean flour or wheat germ in their composition had protein contents up to $38 \%$ higher (Kaminski et al., 2006). Therefore, the low protein contents found in this study were the likely result of the use of basic and economically-viable ingredients adopted by the Child's Pastoral, as well as the substitution of cassava leaves (with higher protein value) by those of cabbage with the aim of reducing the antinutritional factors present in conventional multimixture.

Lipids also have important functions, because when present in appropriate levels they can contribute decisively to an adequate absorption of liposoluble vitamins and, consequently, to the

Table 1. Nutritional information of the conventional multimixture (MM I) and the multimixture enriched with the microencapsulated extract of cupuassu seed by-product (MM II).

\begin{tabular}{|c|c|c|c|}
\hline Energy value / component $t^{a}$ & MM I & MM II & $\mathrm{RDI}^{\mathrm{b}}$ \\
\hline TEV $(\mathrm{kcal})^{\mathrm{c}}$ & $368.2 \pm 8.7^{* *}$ & $344.5 \pm 2.3^{*}$ & 2000 \\
\hline Carbohydrates (g) & $46.6 \pm 1.4^{* *}$ & $33.9 \pm 0.5^{*}$ & 300 \\
\hline Proteins $(\mathrm{g})$ & $1.7 \pm 0.1^{* *}$ & $1.6 \pm 0.0^{*}$ & 75 \\
\hline Total fats (g) & $18.9 \pm 1.5^{* *}$ & $22.5 \pm 0.4^{*}$ & 55 \\
\hline Saturated fats (\%) & $27.9 \pm 0.0^{* *}$ & $21.6 \pm 0.0^{*}$ & 22 \\
\hline Unsaturated fats (\%) & $72.2 \pm 0.01$ & $78.4 \pm 0.01$ & NM \\
\hline Trans fats $(\mathrm{g})$ & $0,00^{*}$ & $0,00^{* *}$ & $\mathrm{NM}^{\mathrm{d}}$ \\
\hline Insoluble dietary fiber (g) & $14.0 \pm 0.2^{*}$ & $17.7 \pm 0.7^{* *}$ & 25 \\
\hline Soluble dietary fiber (g) & $3.3 \pm 0.6^{*}$ & $9.1 \pm 0.6^{* *}$ & 25 \\
\hline Total dietary fiber (g) & $17.3 \pm 0.4^{*}$ & $26.7 \pm 0.1^{* *}$ & 25 \\
\hline Moisture (\%) & $9.4 \pm 0.9^{*}$ & $8.8 \pm 0.3^{*}$ & $\mathrm{NM}^{\mathrm{d}}$ \\
\hline Ash (\%) & $6.0 \pm 0.5^{*}$ & $6.3 \pm 0.1^{*}$ & $\mathrm{NM}^{\mathrm{d}}$ \\
\hline Total polyphenols $\left(\mathrm{mg}_{\mathrm{GAE}}\right)^{\mathrm{e}}$ & - & $48.9 \pm 1.2$ & $\mathrm{NM}^{\mathrm{d}}$ \\
\hline Antioxidant activity $\left(\mathrm{mg}_{\mathrm{TEAC}}\right)^{\mathrm{f}}$ & - & $51.4 \pm 0.4$ & $\mathrm{NM}^{\mathrm{d}}$ \\
\hline \multicolumn{4}{|c|}{ 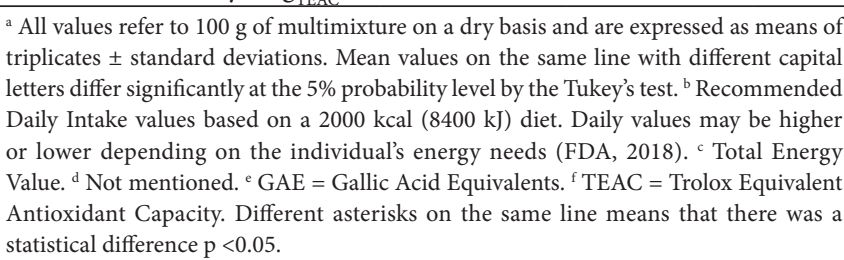 } \\
\hline
\end{tabular}


assimilation of proteins and carbohydrates (Martin \& Li, 2017). As for proteins, the nutritional values of this food fraction may vary greatly depending on the source.

Another important nutritional aspect is the significant presence of dietary fibers in both formulations. Knowledge of the dietary fiber content of foods for human consumption is more interesting than that of crude fiber. For this reason, the Brazilian National Agency of Sanitary Surveillance (ANVISA) establishes that "foods containing at least $6.0 \mathrm{~g}$ of fibers per $100 \mathrm{~g}$ of total solids are classified as foods with a high fiber content" (Brasil, 2005). Based on a RDI of $25 \mathrm{~g}$, which is considered by the European Food Safety Authority (EFSA) a dose sufficient to ensure a normal laxation, both formulations can be classified as high fiber products. In addition, there is evidence of fiber benefits for adult health, such as lower risk of coronary artery disease and type 2 diabetes along with maintenance of body weight (EFSA, 2010).

MM II dietary fiber content $(26.7 \pm 0.1 \mathrm{~g} / 100 \mathrm{~g})$ was $54 \%$ higher than that of conventional multimixture, confirming the improvement of functional qualities mentioned above, and appreciably higher than those of other formulations based on oat flakes $(20.20 \mathrm{~g} / 100 \mathrm{~g})$, cassava flour $(19.81 \mathrm{~g} / 100 \mathrm{~g})$ or soybean flour (14.66 g/100g) (Kaminski et al., 2006).

MM II also had contents of insoluble (IDF $=17.7 \pm 0.7 \mathrm{~g} / 100 \mathrm{~g}$ ) and soluble $(\mathrm{SDF}=9.1 \pm 0.6 \mathrm{~g} / 100 \mathrm{~g})$ dietary fibers 26 and $176 \%$ higher than MM I, respectively. According to Delcour et al. (2016), diets with different SDF/IDF ratios may result in different physiological effects. A higher IDF proportion, as in the case of MM I (80.9\%), a) leads to greater absorption and retention of water, b) makes the movement of digestive bolus in the gastrointestinal tract easier, c) increases stool volume and speed of transit, and d) reduces intestinal constipation, hemorrhoids, varicose veins and diverticulitis. On the other hand, a higher SDF proportion, as in the case of MM II (34.1\%), may aid in the control and decrease of LDL cholesterol, blood glucose and insulin levels, as well as stimulate fermentation by beneficial intestinal bacteria that produce short-chain fatty acids. Finally, IDF values higher than those of SDF in both formulations may be related to the high rice bran and green leaves proportions.

MM I and MM II samples had moisture contents statistically coincident $(p>0.05)$ with that of $\mathrm{ME}(9.7 \pm 0.4 \%)$ and within the limits established by the Brazilian legislation for flours, starches and bran (15\%) as well as for cassava flour (13\%) (Brasil, 1995, 2005).

The fixed mineral residue, corresponding to the ash content, of MM I and MM II (Table 1$)$ was statistically coincident $(p>0.05)$ and almost 5 -fold that of $\mathrm{ME}(1.3 \pm 0.3 \%)$, due to the abundance of inorganic compounds in the multimixture.

As mentioned above, MM I composition followed the recommendations of the Child's Pastoral, which produces and uses it as a food supplement for preventing and reducing child malnutrition. To improve the multimixture functional quality, the new MM II formulation was integrated with $5.0 \mathrm{~g}$ of $10 \%(\mathrm{w} / \mathrm{w})$ $\mathrm{ME}$ as an additive, which resulted in total polyphenol content of $48.9 \mathrm{mg}_{\mathrm{GAE}} / 100 \mathrm{~g}$ and antioxidant activity of $51.4 \mathrm{mg}_{\mathrm{TEAC}} / 100 \mathrm{~g}$
(Table 1). Besides their antioxidant activity (Barros et al., 2016; Can-Cauich et al., 2017), food polyphenols provide protection against the development of chronic diseases such as cardiovascular diseases, type 2 diabetes and certain cancers (Martin \& Li, 2017).

These characterization results demonstrate that the ME-enriched formulation may be an advance in terms of functional compounds compared with the conventional multimixture, thanks to the high antioxidant content of the extract.

\subsection{Fatty acids composition}

Fatty acid profiles of the two multimixtures showed statistically significant variations $(p<0.05)$ in the contents of all major fatty acids (Table 2).

In particular, MM II had a content of saturated fatty acids, especially palmitic and stearic acids, about $22 \%$ lower than that of MM I, which not only reduced the TEV by around $14 \%$, but also avoided exceeding the corresponding RDI (22 g) (Table 1). The regulatory bodies do in fact establish that one must consume the lowest possible content of saturated fatty acids for a nutritionally adequate diet (Institute of Medicine, 2006; Food and Drug Administration, 2018).

In addition, the levels of monounsaturated fatty acids (MUFA) and polyunsaturated fatty acids (PUFA) of MM II were about $10 \%$ higher than those of MM I. As is well known, PUFAs confer human health benefits, since $\omega-6$ and $\omega-3$ fatty acids are essential, cannot be synthesized by the body and must then be obtained only through diet. Among them, linoleic acid acts as a precursor of arachidonic acid, which in turn is the precursor for the synthesis of eicosanoids (prostaglandins, thromboxanes and leukotrienes), an important class of mediators involved in the inflammation process (Martin \& Li, 2017). PUFAs contained in the multimixture can be ascribed mainly to oils present in sunflower seeds, chestnuts and seeds, which, admittedly, contribute to proper metabolic functioning and human health maintenance (Müller et al., 2004).

Table 2. Fatty acid profile and functional quality of lipid fractions of the conventional multimixture (MM I) and that enriched with the microencapsulated extract of the cupuassu seed by-product (MM II).

\begin{tabular}{lcc}
\hline \multicolumn{1}{c}{ Fatty acid profile ${ }^{\text {a }}$} & MM I (\%) & MM II (\%) \\
\hline Saturated fatty acids & $21.29 \pm 0.02^{* *}$ & $18.08 \pm 0.00^{*}$ \\
Palmitic acid (C16:0) & $6.56 \pm 0.01^{* *}$ & $3.49 \pm 0.02^{*}$ \\
Stearic acid (C18:0) & \\
Monounsaturated fatty acid & $40.81 \pm 0.00^{*}$ & $44.32 \pm 0.00^{* *}$ \\
Oleic acid (C18:1, $\omega-9)$ & & \\
Polyunsaturated fatty acid & $31.34 \pm 0.01^{*}$ & $34.11 \pm 0.01^{* *}$ \\
Linoleic acid (C18:2, $\omega-6)$ & & \\
Lipid functional quality & $0.29^{* *}$ & $0.23^{*}$ \\
AI $^{\mathrm{b}}$ & $0.77^{* *}$ & $0.55^{*}$ \\
$\mathrm{TI}^{\mathrm{c}}$ & $3.39^{*}$ & $4.34^{* *}$ \\
$\mathrm{HH}^{\mathrm{d}}$ & & \\
\hline
\end{tabular}

${ }^{a}$ All values are the means of two determinations \pm standard deviations. Mean values on the same line with different capital letters differ significantly at the $5 \%$ probability level by the Tukey's test. ${ }^{b}$ Atherogenicity index. ${ }^{c}$ Thrombogenicity index. ${ }^{d}$ Ratio between hypocholesterolemic and hypercholesterolemic fatty acids. Different asterisks on the same line means that there was a statistical difference $\mathrm{p}<0.05$. 
Fatty acids composition allowed us to evaluate the functional quality of lipid fractions. The ratio between hypocholesterolemic and hypercholesterolemic fatty acids $(\mathrm{HH})$ was in MM II $28 \%$ higher than in MM I. It is worth remembering that the higher such an index, the more functionally suitable the oil or fat, being specifically related to cholesterol metabolism (Martin \& Li, 2017). The atherogenicity (AI) and trobogenicity (TI) indexes, which correlate pro- and anti-atherogenic acids, were 20 and 29\% lower for MM II than for MM I (Table 2).

These indices indicate the potential for stimulating platelet aggregation (Turan, Sönmez \& Kaya, 2007), that is, the lower the AI and TI values, the greater the amount of anti-atherogenic fatty acids, and consequently the greater the potential for prevention of coronary diseases. The lower AI and TI values of MM II are consistent with its lower saturated fatty acids content compared to MM I (Table 1) and suggest that multimixture enrichment with the cupuassu seed by-product may contribute to the prevention of coronary diseases as well as anti-inflammatory processes.

These results as a whole confirm that the multimixture had an improved functional composition when enriched with ME.

\subsection{Macro- and micromineral composition}

Calcium, which is one of the most important macrominerals of human body and plays a keyrole in bone and dental health (Institute of Medicine, 2006; Berto et al., 2015), was abundant both in MMI (225.5 $\pm 12.0 \mathrm{mg} / 100 \mathrm{~g})$ and MM II $(258.7 \pm 16.0 \mathrm{mg} / 100 \mathrm{~g})$, accounting for about one fourth of the mean RDI for adults (FDA, 2018). MM II had sodium $(35.1 \pm 0.4 \mathrm{mg} / 100 \mathrm{~g})$ and potassium $(1384.4 \pm 0.8 \mathrm{mg} / 100 \mathrm{~g})$ contents within the values established as being acceptable by Institute of Medicine (2006), constituting only 1.5 and $23.6 \%$ of their respective RDIs.

Among the microminerals, Fe and $\mathrm{Zn}$ levels in MM II $(5.1 \pm 0.1 \mathrm{mg} / 100 \mathrm{~g}$ and $2.6 \pm 0.2 \mathrm{mg} / 100 \mathrm{~g}$, respectively) did not differ statistically from those in MM I $(5.4 \pm 0.1$ and $2.7 \pm 0.2 \mathrm{mg} / 100 \mathrm{~g})$ $(p>0.05)$, while that of $\mathrm{Cu}(\mathrm{MM} \mathrm{I}=0.35 \pm 0.10 \mathrm{mg} / 100 \mathrm{~g}$ and $\mathrm{MM}$ II $=0.45 \pm 0.10 \mathrm{mg} / 100 \mathrm{~g}$ ) was almost $30 \%$ higher, suggesting a high content of this metal in ME. These values correspond to mean percentages of about 28, 25 and $50 \%$ of maximum RDIs for adults (Institute of Medicine, 2006), while the $\mathrm{Mn}(9.9 \pm 0.1 \% \mathrm{mg} / 100 \mathrm{~g})$ content in both formulations was approximately four times higher (Institute of Medicine, 2006; Food and Drug Administration, 2018). Mg and Mn, whose contents were above their corresponding RDIs, should be related to the suggested consumption of only $25 \%$ of the expressed unit (mg/100g), referring to a homemade tablespoon. $\mathrm{Zn}$ is important for children growth and development, being involved in various enzyme reactions of the metabolism of proteins, sugars and fats as well as the regulation of gene expression (Bhowmik et al., 2010). No quantifiable levels of $\mathrm{Pb}$ were detected in both formulations.

A comparative analysis with foods largely consumed by the population of the State of Pará, such as frozen pulp of açaí and cooked cassava (Table 3), shows for MM II better nutritional and mineral values, especially of TEV, proteins, dietary fiber, and minerals.

In view of the above, it is noteworthy that, for a large part of Brazilian population, there is a significant limitation of nutrients in foods due to the limited consumption of fruits and vegetables (Brasil, 2014). This situation becomes even more serious for school-age children, who need a more diversified diet for optimal growth and mental development.

\subsection{Morphological analysis}

Scanning Electron Microscopy confirmed the significant contents of total dietary fiber, carbohydrates and proteins in MM II (Figure 1), mainly because it was made up only of food grains and cupuassu by-product.

In particular, panel A shows starch granules irregularly dispersed on the formulation surface (highlighted arrows). These structures are oval- or rounded-shape polysaccharide reserves that have smooth surfaces probably due to the strong interaction between starch and proteins. It is also evident a fragment of cell membrane that has a fibrillar nutritional function, i.e., it

Table 3. Nutritional parameters of multimixture enriched with the microencapsulated extract of cupuassu seed by-product (MM II) in comparison with frozen açaí pulp and cooked cassava.

\begin{tabular}{lccc}
\hline \multicolumn{1}{c}{ Nutritional parameter } & MM II & Frozen pulp of açaía $^{\text {a }}$ & Cooked cassava $^{\mathrm{a}}$ \\
\hline TEV $(\mathrm{kcal} / 100 \mathrm{~g})$ & 278 & 58 & 125 \\
Proteins $(\mathrm{g} / 100 \mathrm{~g})$ & 1.6 & 0.8 & 0.68 \\
Lipids $(\mathrm{g} / 100 \mathrm{~g})$ & 9.1 & 3.9 & 0.30 \\
Carbohydrates $(\mathrm{g} / \mathrm{100g})$ & 47 & 6.2 & 30.1 \\
Dietary fiber $(\mathrm{g} / 100 \mathrm{~g})$ & 27 & 2.6 & 1.6 \\
$\mathrm{Ca}(\mathrm{mg} / 100 \mathrm{~g})$ & 258 & 35 & 19 \\
$\mathrm{Mg}(\mathrm{mg} / 100 \mathrm{~g})$ & 660 & 17 & 27 \\
$\mathrm{Mn}(\mathrm{mg} / 100 \mathrm{~g})$ & 9.9 & 6.2 & 0.06 \\
$\mathrm{P}(\mathrm{mg} / 100 \mathrm{~g})$ & 1384 & 16 & 22 \\
$\mathrm{Fe}(\mathrm{mg} / 100 \mathrm{~g})$ & 5.1 & 0.4 & 0.1 \\
$\mathrm{Na}(\mathrm{mg} / 100 \mathrm{~g})$ & 35 & 5.0 & 1.0 \\
$\mathrm{~K}(\mathrm{mg} / 100 \mathrm{~g})$ & 1110 & 124 & 100 \\
Zn $(\mathrm{mg} / 100 \mathrm{~g})$ & 2.6 & 0.3 & 0.2 \\
\hline
\end{tabular}

aNúcleo de Estudos e Pesquisas em Alimentação (2011). 

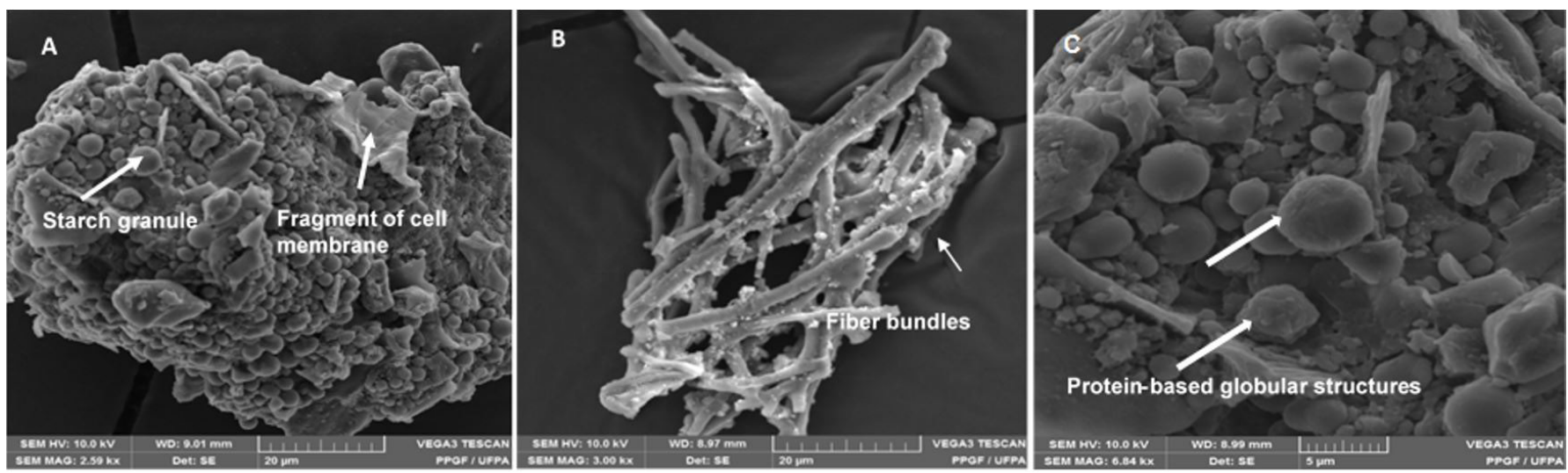

Figure 1. Scanning Electron Microscopy images of the multimixture enriched with the microencapsulated extract of cupuassu seed by-product.

(A) Structures of starch granules and cell membrane fragment (2600 x magnification), (B) Structure of fiber bundles (3000 x magnification),

(C) Characteristic protein structures (6840 x magnification).
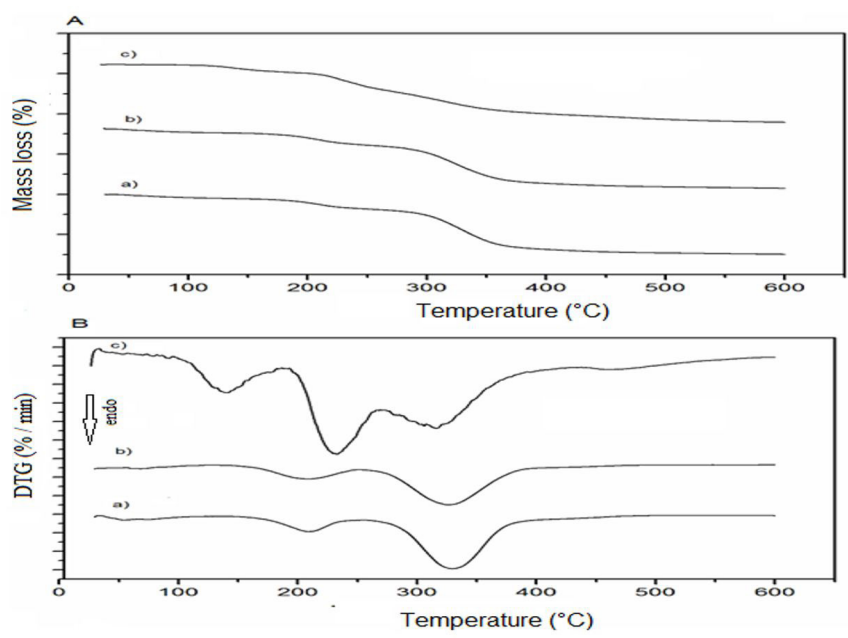

Figure 2. Thermogravimetric curves of a) conventional multimixture, b) multimixture enriched with the microencapsulated extract of cupuassu seed by-product, and c) microcapsules of the extract of cupuassu seed by-product obtained under optimum microencapsulation conditions. A) TG curves; B) DTG curves.

acts increasing the speed of intestinal transit, being composed of amiloplasts and residues of reserve parenchyma. It can also improve the product technological functions because of its ability to absorb hydrophilic and lipophilic components. Its fragmented and spiculate structure was probably due to intense grinding and drying of the material during sample preparation.

In panel B, one can identify fiber bundles, consistently with the significant levels of total, soluble and insoluble fibers quantified in the multimixture. The presence of high fiber contents in foods, as is the case of MM II, follows the principles of preventive action against the occurrence of pathogenic diseases, especially the colorectal cancer (Delcour et al., 2016).

Finally, panel C shows structures with spherical, oval or spongy surfaces similar to those observed for Brazil nut proteins by Santos et al. (2010), who suggested that they may have been caused by lipid extraction and related to protein matrix.

\subsection{Thermogravimetric analysis}

Figure 2 shows the thermal behavior of both multimixtures and ME. The TG/DTG curves do refer to the mass losses due to degradation and/or decomposition of sample components. In panel $\mathrm{B}$, referring to the DTG curves that allow for better visualization of thermal degration events, the endothermic peaks may be related to the low protein content of multimixtures.

These curves reveal a certain thermal stability up to about $110{ }^{\circ} \mathrm{C}$ for MM I and MM II and $150{ }^{\circ} \mathrm{C}$ for ME, with mass losses around 4.5 and $10.5 \%$ respectively. These reductions may be related to loss of material moisture. Both MM I and MM II were thermally stable at $190{ }^{\circ} \mathrm{C}$, having suffered initial mass losses of 19.2 and $18.3 \%$, respectively, which can be attributed to the degradation of constituents such starch and fibers as well as the decomposition of residual lipid material. At higher temperatures, the two multimixtures showed identical thermal behavior, characterized by two important endothermic mass loss events occurred between 190 and $304^{\circ} \mathrm{C}(19.2 \%)$ and between 304.5 and $418{ }^{\circ} \mathrm{C}(41.5 \%)$. The same took place with $\mathrm{ME}$ in the temperature ranges of $202-245^{\circ} \mathrm{C}(20.3 \%)$ and $270-369^{\circ} \mathrm{C}$ (38.4\%). All these events can be explained by carbonization of organic compounds. At temperatures above $400{ }^{\circ} \mathrm{C}$ no mass loss was observed, suggesting total burning of the organic constituents of all materials.

These results show that, in the temperature range commonly used for food products $\left(100-300^{\circ} \mathrm{C}\right)$, the multimixture containing microencapsulated cupuassu seed extract did not undergo major variations or significant mass losses that could prevent its use as a nutritional integrator.

\section{Conclusion}

The nutritional and functional qualities of a multimixture enriched with the microencapsulated extract of cupuassu seed by-product were compared with those of a conventional multimixture. The results point it as a promising raw material to be used as an alternative dietary supplement in basic foods. Both multimixtures had suitable contents of macronutrients, total fiber and unsaturated fats, which play important 
nutritional and functional roles to human health thanks to their beneficial properties in the prevention of pathologies, mainly cardiovascular diseases. The contents of microminerals were equal to or higher than the RDIs recommended for a $2000 \mathrm{kcal}$ diet. Thermogravimetric analyses highlighted excellent stability of both multimixtures when temperature was progressively increased within the typical working range for food preparations and small variations or limited mass losses. These results suggest the use of the microencapsulated extract of cupuassu seed by-product as a basic ingredient to enrich conventional multimixtures or to prepare new food products.

\section{Acknowledgements}

The authors thank the Natura Cosmetic for providing the cupuassu by-product and Prof. Dr. Kelly Dantas, coordinator of the atomic absorption laboratory (UFPA), for conducting the analyses on minerals. This work was supported by the National Council for Scientific and Technological Development (CNPq) (Project 310418/2012-7/CNPq), the Amazonia Foundation for Studies and Research of the State of Pará (FAPESPA), the Coordination for the Improvement of Higher Education Personnel (CAPES) for the financial support and scholarship (Process No. 99999.003074/2015-03) and the Postgraduate ProResearch (PROPESP/UFPA).

\section{References}

Association of Official Analytical Chemists - AOAC. (2010). Official methods of analysis (18th ed.). Washington: AOAC.

Barros, H. R. M., García-Villalba, R., Tomás-Barberán, F. A., \& Genovese, M. I. (2016). Evaluation of the distribution and metabolism of polyphenols derived from cupuassu (Theobroma grandiflorum) in mice gastrointestinal tract by UPLC-ESI-QTOF. Journal of Functional Foods, 22, 477-489. http://dx.doi.org/10.1016/j.jff.2016.02.009.

Berto, A., Silva, A. F., Visentainer, J. V., Matsushita, M., \& Souza, N. S. (2015). Proximate compositions, mineral contents and fatty acid compositions of native Amazonian fruits. Food Research International, 77, 441-449. http://dx.doi.org/10.1016/j.foodres.2015.08.018.

Bezerra, C. V., Rodrigues, A. M. C., Oliveira, P. D., Silva, D. A., \& Silva, L. H. M. (2017). Technological properties of Amazonian oils and fats and their applications in the food industry. Food Chemistry, 221, 1466-1473. http://dx.doi.org/10.1016/j.foodchem.2016.11.004. PMid:27979116.

Bhowmik, D., Chiranjib, K. P., \& Kumar, S. (2010). A potential medicinal importance of zinc in human health and chronic disease. International Journal of Pharma and Bio Sciences, 1(1), 5-11.

Brasil. (1995, September 1). Estabelece a norma de identificação e qualidade, acondicionamento e transporte de farinhas de mandioca para fins de comercialização (Portaria n 554, de 30 de agosto de 1995). Diário Oficial [da] República Federativa do Brasil, seção 113515.

Brasil, Agência Nacional de Vigilância Sanitária, Ministério da Saúde. (2005, September 23). Aprova o regulamento técnico para produtos de cereais, amidos, farinhas e farelos (Resolução RDC no 263 , de 23 de setembro de 2005). Diário Oficial [da] República Federativa do Brasil, seção 1. pp. 368-369.

Brasil. Ministério da Saúde. Secretaria de atenção à saúde. Departamento de Atenção Básica (2014). Guia alimentar para a população brasileira (2nd ed.). Brasilia.
Can-Cauich, C. A., Sauri-Duch, E., Betancur-Ancona, D., Chel-Guerrero, L., González-Aguilar, G. A., Cuevas-Glory, L. F., Pérez-Pacheco, E., \& Moo-Huchin, V. M. (2017). Tropical fruit peel powders as functional ingredients: Evaluation of their bioactive compounds and antioxidant activity. Journal of Functional Foods, 37, 501-506. http://dx.doi.org/10.1016/j.jff.2017.08.028.

Costa, R. S., Santos, O. V., Lannes, S. C. S., Casazza, A. A., Aliakbarian, B., Perego, P., Ribeiro-Costa, R. M., Converti, A., \& Silva Júnior, J. O. C. (2019). Bioactive compounds and value-added applications of cupuassu (Theobroma grandiflorum Schum.) agroindustrial byproduct. Food Science and Technology (Campinas). http://dx.doi. org/10.1590/fst.01119.

Da Costa, R. S., Teixeira, C. B., Gabbay Alves, T. V., Ribeiro-Costa, R. M., Casazza, A. A., Aliakbarian, B., Converti, A., Silva Júnior, J. O. C., \& Perego, P. (2018). Optimization of spray drying conditions to microencapsulate cupuassu (Theobroma grandiflorum) seed byproduct extract. Natural Product Research. http://dx.doi.org/10.10 80/14786419.2018.1462178. PMid:29656659.

Delcour, J. A., Aman, P., Courtin, C. M., Hamaker, B. R., \& Verbeke, K. (2016). Prebiotics, fermentable dietary fiber, and health claims. Advances in Nutrition, 7(1), 1-4. http://dx.doi.org/10.3945/ an.115.010546. PMid:26773010.

European Food Safety Authority - EFSA (2010). Scientific opinion on dietary reference values for carbohydrates and dietary fibre. EFSA Journal, 8(1462), 1-77.

Esteller, M. S., Zancanaro Júnior, O., \& Lannes, S. C. S. (2006). Bolo de "chocolate" produzido com pó de cupuaçu e kefir. Revista Brasileira de Ciências Farmacêuticas, 42(3), 447-454. http://dx.doi.org/10.1590/ S1516-93322006000300014.

Ferreira, H. S., Cavalcante, S. A., \& Assunção, M. L. (2010). Chemical composition and efficacy of the multimixture as a dietary supplement: a literature review. Ciencia \& Saude Coletiva, 15(Suppl. 2), 3207-3220. http://dx.doi.org/10.1590/S1413-81232010000800026. PMid:21049162.

Food and Agriculture Organization of the United Nations - FAO. (2017). SOFI: The State of Food Insecurity in the World. Rome: FAO. Retrieved from: http://www.fao.org/news/story/pt/item/243923/icode/.

Food and Drug Administration - FDA. (2018). Food Guidance \& Regulation. Maryland: FDA. Retrieved from: https://www.fda.gov/ Food/GuidanceRegulation/default.htm

Hernandez-Santos, B., Vivar-Vera, M. A., Rodríguez-Miranda, J., Herman-Lara, E., Torruco-Uco, J. G., Acevedo-Vendrell, O., \& Martınez-Sanchez, C. E. (2015). Dietary fibre and antioxidant compounds in passion fruit (Passiflora edulis f. flavicarpa) peel and depectinised peel waste. International Journal of Food Science \& Technology, 50(1), 268-274. http://dx.doi.org/10.1111/ijfs.12647.

Institute of Medicine - IOM. (2006). Dietary reference intakes: The essential guide to nutrient requirements. Washington: The National Academy Press.

Kaminski, T. A., Silva, L. P., \& Bagetti, M. (2006). Centesimal and mineral composition of multimixtures derived from central region of Rio Grande do Sul - Brazil. Revista do Instituto Adolfo Lutz, 65(3), 186-193.

Madruga, M. S., Santos, H. B., Bion, F. M., \& Antunes, N. L. M. (2004). Nutritional evaluation of a diet supplement with "multimistura": study with rats. Food Science and Technology, 24(1), 129-133. http:// dx.doi.org/10.1590/S0101-20612004000100023.

Martin, C., \& Li, J. (2017). Medicine is not health care, food is health care: plant metabolic engineering, diet and human health. The New Phytologist, 216(3), 699-719. http://dx.doi.org/10.1111/nph.14730. PMid:28796289. 
Molina-Ramírez, C., Castro, C., Zuluaga, R., \& Gañán, P. (2018). Physical characterization of bacterial cellulose produced by Komagataeibacter medellinensis using food supply chain waste and agricultural byproducts as alternative low-cost feedstocks. Journal of Polymers and the Environment, 26(2), 830-837. http://dx.doi.org/10.1007/ s10924-017-0993-6.

Müller, M., Prado, I. N., Lobo Júnior, A. R., Capovilla, L. C. T., \& Rigolon, L. P. (2004). Fontes de gordura ômega-3 e ômega-6 sobre a digestibilidade aparente de novilhos de corte confinados. Acta Scientiarum. Animal Sciences, 26(3), 393-398. http://dx.doi. org/10.4025/actascianimsci.v26i3.1834.

Núcleo de Estudos e Pesquisas em Alimentação - NEPA. (2011). Tabela Brasileira de Composição de Alimentos - TACO (4th ed.). Campinas: UNICAMP.

Pugliese, A. G., Tomas-Barberan, F. A., Truchado, P., \& Genovese, M. (2013). Flavonoids, proanthocyanidins, vitamin C, and antioxidant activity of Theobroma grandiflorum (cupuassu) pulp and seeds. Journal of Agricultural and Food Chemistry, 61(11), 2720-2728. http://dx.doi.org/10.1021/jf304349u. PMid:23431956.

Rodrigues, A. M. C., Darnet, S., \& Silva, L. H. M. (2010). Fatty acid profiles and tocopherol contents of buriti (Mauritia flexuosa), patawa (Oenocarpus bataua), tucuma (Astrocaryum vulgare), mari (Poraqueiba paraensis) and inaja (Maximiliana maripa) fruits. Journal of the Brazilian Chemical Society, 21(10), 2000-2004. http://dx.doi. org/10.1590/S0103-50532010001000028.

Sampaio, R. C. A., Costa, R. S., Souza, C. R. F., Duarte, A. P. Jr, RibeiroCosta, R. M., Costa, C. E. F., Oliveira, W. P., Converti, A., \& Silva Júnior, J. O. C. (2016). Thermal characterization of Arrabidaea chica (Humb. \& Bonpl.) B. Verl. dry extracts obtained by spray dryer. Journal of Thermal Analysis and Calorimetry, 123(3), 2469-2475. http://dx.doi.org/10.1007/s10973-015-5123-x.

Santos, O. V., Lopes, A. S., Azevedo, G. O., \& Santos, A. C. (2010). Processing of Brazil-nut flour: characterization, thermal and morphological analysis. Food Science and Technology (Campinas), 30(Suppl. 1), 264-269. http://dx.doi.org/10.1590/S0101-20612010000500040.

Santos-Silva, J., Bessa, R. J. B., \& Santos-Silva, F. (2002). Effect of genotipe, feeding system and slaughter weigt on the quality of light lambs. II. Fatty acid composition of meat. Livestock Production Science, 77(2-3), 187-194. http://dx.doi.org/10.1016/S0301-6226(02)00059-3.

Turan, H., Sönmez, G., \& Kaya, Y. (2007). Fatty acid profile and proximate composition of the thornback ray (Raja clavata, L. 1758) from the Sinop coast in the Black Sea. Journal of Fisheries Sciences, 1(2), 97-103.

Ulbricht, T. L. V., \& Southgate, D. A. T. (1991). Coronary heat disease: seven dietary Anthelmintic effect of three tannin-rich Mediterranean shrubs in naturally infected sheep. Small Ruminant Research, 123(1), 179-182. 